\title{
Understanding LAW AND ReLIGION AS CultuRE: Making Room for Meaning in the Public Sphere
}

\author{
Benjamin L. Berger*
}

\section{INTRODUCTION}

The relationship between law and religion in contemporary civil society has been a topic of increasing social interest and importance in Canada in the past many years. We have seen the practices and commitments of religious groups and individuals become highly salient on many issues of public policy, including the nature of the institution of marriage, the content of public education, and the uses of public space, to name just a few. As the vehicle for this discussion, I want to ask a straightforward question: When we listen to our public discourse, what is the story that we hear about the relationship between law and religion? How does this topic tend to be spoken about in law and politics - what is our idiom around this issue - and does this story serve us well? Though straightforward, this question has gone all but unanswered in our political and academic discussions. We take for granted our approach to speaking about - and, therefore, our way of thinking about - the relationship between law and religion. In my view, this is most unfortunate because this taken-for-grantedness is the source of our failure to properly understand the critically important relationship between law and religion.

So how do we normally speak about the relationship between law and religion? Think back to the newspaper articles, radio shows, and court decisions that have addressed this newly invigorated relationship in Canada. Upon

* This piece is a lightly edited version of a public lecture delivered on 5 November 2004 in Edmonton, Alberta, as part of Conversations on Mars Hill: Lecture Series on the Intersection of Religion and Civil Life. The lecture was based on the author's ongoing doctoral dissertation project. reflection, what you might notice is that almost everyone - and particularly politicians and the courts - speak in a very particular and amazingly stable idiom. The story tends to go like this: when law and religion meet in contemporary society, the task is simply for the law to accommodate, tolerate, or make space for the particular religiouscultural claim among the variety of such cultural claims in this highly pluralistic Canadian society. This account holds that, in a polity in which constitutionalism and legal liberalism have become so entrenched, the primary means by which this task can be achieved is by properly defining and balancing the rights in issue.

Two features of this story deserve remark. First, note that this idiom treats law and religion as fundamentally different phenomena. Whereas religion is a culture, law sits above it, seeking to integrate religious claims among the many cultural claims that it oversees. I will later challenge this notion. Second, note that the main message of this story is a fundamentally hopeful one: that the goal of accommodation and appropriate balancing can be achieved. On this account, properly defining rights or making space for religion is not necessarily an easy task, but one that simply requires attention and effort to achieve. In this way, the story that most of us tell and hear about the relationship between law and religion places enormous faith in law's ability to resolve the cultural claims, and resulting tensions, that it encounters. Law - constitutional law in particular - will do the job if one just keeps working at it. In short, this understanding of the problem assumes the existence of a solution.

The main problem with this story - the problem that pushes me to seek a more satisfying alternative - is that it is not true to our historical or 
contemporary experience of the relationship between law and religion. The various tensions that we feel in Canada today are not new to the scene. They are tensions that have been sustained and pronounced over the history of this country and, indeed, of the two European nations upon which this country is partly built. Yet over all this time - this long opportunity to come to terms with the relationship and to "fine tune" the law - the issue has not abated or been resolved. New issues of public policy arise and the dilemma reappears, as exigent and seemingly intractable as before. It is not a satisfying account of the way that we see law and religion work. The story is a comforting and simple one, but one that does not ring true.

\section{THE INFORMING VIEW OF LAW}

The underlying problem with the way that we currently approach the interaction of law and religion lies in the implicit conception of law upon which this current understanding is founded. In this story, the meeting taking place is between law as something given and standing above the fray of culture, on the one hand, and a cultural claim called religion, on the other. The law is tasked with making room or space within it for the culture; law is called upon to accommodate or tolerate cultures - to adjust in a way that harmonizes the competing cultural views for which it is responsible. The unspoken understanding of law in this story is of the law as a functional adjunct to a properly working state and, essentially, a mechanism for maintaining social stability and implementing government aims. ${ }^{1}$ On this view, law is an instrument, albeit a particularly impressive one. Law is seen as endlessly malleable and perfectly adaptive. The vision is one of the law being able to create a

This embedded conception of law bears striking similarity to what one scholar has called the "folk model" of law. See Sally Falk Moore, Law as Process: An Anthropological Approach (London and Boston: Routledge \& K. Paul, 1978) at 1-2. Moore uses the following description from a 1971 handbook for law students as emblematic of this folk model: "The Law' in the broad sense of our whole legal system with its instructions, rules, procedures, remedies, etc. is society's attempt, through government, to control human behaviour and prevent anarchy, violence, oppression and injustice by providing and enforcing orderly, rational, fair and workable alternatives to the indiscriminate use of force by individuals or groups in advancing or protecting their interests and resolving their controversies. 'Law' seeks to achieve both social order and individual protection, freedom and justice" (at 2). coherent social system. Whatever difficult cultural claims are made within a society, law can meet the challenge by adapting to properly accommodate or make space for these claims. Thus, where there is a clash of rights, let us say a clash between freedom of religion and the right to equality or freedom to associate, coherence is a tenable possibility; all turns on the law as instrument making the right fine-tuning adjustment.

It is apparent how this vision of law supports the conventional story that we tell about law and religion. Constitutional law is simply a given system of social ordering - an instrument - as opposed to religion, which is a culture. The law is not intrinsically committed to any particular goods or social ends and, as such, nothing should stand in the way of this instrument adapting to accommodate culture. The problem, to the extent that one exists, is simply one of finding the right configuration for the system so that it can make space within itself for this particular cultural commitment. ${ }^{2}$

\section{THE CLAIM: LAW AS CULTURE}

As I have said, however, the flaw in this view is that it does not supply a satisfying account of our experience of the interaction of law and religion. Law has struggled mightily, but it has never been able to resolve its tensions with religion. Far from the law functionally tolerating or accommodating this culture within its overarching structure, law and religion have been locked in a durable tension. Why? My argument is that this descriptive failure is a product of the fact that the vision of law implicit in the conventional account of the relationship between law and

\footnotetext{
Manifestations of this view of the relationship between law and religion can be found both in Canadian jurisprudence (see e.g., Trinity Western University v. British Columbia College of Teachers, [2001] 1 S.C.R. 772, 2001 SCC 31, online: CanLII $<$ http://www.canlii.org/ca/cas/scc/2001/2001scc31.html>; Chamberlain v. Surrey School District No. 36, [2002] 4 S.C.R. 710, 2002 SCC 86, online: CanLII: <http://www.canlii. org $/ \mathrm{ca} / \mathrm{cas} / \mathrm{scc} / 2002 / 2002 \mathrm{scc} 86 . \mathrm{html}>$ ) and in the scholarly literature (see e.g., James R. Beattie, Jr., "Taking Liberalism and Religious Liberty Seriously: Shifting Our Notion of Toleration from Locke to Mill" (2004) 43:2 Catholic Lawyer 367; Iain T. Benson, "Notes Towards a (Re)definition of the 'Secular'" (2000) 33:3 University of British Columbia Law Review 519; and Paul Horwitz, "The Sources and Limits of Freedom of Religion in a Liberal Democracy: Section 2(a) and Beyond" (1996) 54:1 University of Toronto Faculty of Law Review 1).
} 
religion is flawed: the problem is with how we think of the law. What is needed is a revision of our conception of the respective natures of law and religion. I want to suggest that, on an important axis, law and religion share a critical similarity: they are both cultures.

It would be fair to demand by now a definition of what I mean when I use the term "culture." Indeed, this is an important point of understanding. I take the term "culture" to refer to an interpretive horizon, composed of sets of symbols and categories of thought, out of which meaning can be given to experience. ${ }^{3}$ It is a system of background understandings that inform, and the process by which we generate, our interpretations of our world. When, through the law, we examine our experiences and the events that take place in our world, we do so within an already-meaningful context. This meaningful and meaning-giving context is a culture. It comprises the context and process of understanding, as well as the resulting expressions. Culture is both a text and the language out of which the text is constituted.

The claim that law is a culture is not an intuitive one. I will spend some time supporting my claim of law as culture, but in the meantime, and with this definition of culture in mind, consider the implications for our topic of understanding law as culture.

If Canadian constitutional law is not simply a given mechanism for social ordering but is a

In the larger project that forms the basis for this piece, I derive this conception of "culture" from an analysis of the term's treatment in two academic traditions, interpretive anthropology and philosophical hermeneutics. In the former discipline, central works include Clifford Geertz, The Interpretation of Cultures (New York: Basic Books, 1973); Clifford Geertz, Available Light: Anthropological Reflections on Philosophical Topics (Princeton and Oxford: Princeton University Press, 2000); Mary Douglas, Purity and Danger: An Analysis of Concepts of Pollution and Taboo (London and New York: Routledge, 2002); James Clifford, The Predicament of Culture (Cambridge: Harvard University Press, 1988); and John L. Comaroff \& Jean Comaroff, Ethnography and the Historical Imagination (Boulder: Westview Press, 1992). In the field of hermeneutics, I pay most attention to the thought of Wilhelm Dilthey, but consider as well the development of Dilthey's insights in Gadamer's work. See Wilhelm Dilthey, Meaning in History: W. Dilthey's Thoughts on History and Society, ed. by H. P. Rickman (London: George Allen \& Unwin Ltd., 1961); Wilhelm Dilthey, The Formation of the Historical World in the Human Sciences, vol. III (Princeton and Oxford: Princeton University Press, 2002); and Hans-Georg Gadamer, Truth and Method, $2 \mathrm{~d}$ ed., revised and trans. by Joel Weinsheimer and Donald G. Marshall (New York: Crossroad, 1989). worldview, a system of symbols and beliefs that supplies a framework of meaning, then what we are seeing in the interaction between law and religion is not a challenge of accommodation or systemic fine-tuning, but a meeting of meaningladen cultures. Most importantly, if this is true, then the law, as a culture, is not infinitely malleable, tolerant, and accommodating. Like all cultures, it has meanings that cannot be compromised. As in all cultures, in law there are certain nonnegotiable beliefs and structures of understanding. Thus, there is the fact of incommensurability: the reality that there are points at which law and religion cannot come together - points at which, as cultures, law and religion must differ and conflict ${ }^{4}-$ and, therefore, points at which law and religion are not capable of being harmonized.

Consequently, the idiom must change from one appropriate to the folk model of law "making room" and "making space" - to one appropriate to meaning-giving cultures - one of a clash of cultural systems. "Resolution" is not a realistic goal. What are in play are ways of being and understanding. So long as there are different meaning systems - different cultures - tensions will be a reality. The story that we tell about the relationship between law and religion must change.

\section{DEFENDING LAW AS CULTURE}

This kind of thesis would be unremarkable if we were talking about two phenomena more readily understood as cultures. Take, for example, Jewish and Buddhist cultures. It would not surprise you if I were to point out that people living within these two cultures are living within two very different systems of understanding their world, and two very different frameworks of meaning. Nor would it surprise you if I were to claim that though there might be many points at which Buddhism and Judaism can speak to one another, there are also points at which the systems of meaning and worldviews will irreconcilably differ.

Naturally, these cultures will differ in their shape and claims. The point is not that religion and law, as cultures, are the same; rather, as cultures, they make claims about the meaning of experience and where these claims come into contact, we are faced with the possibility of incommensurability. 
The reason that this thesis is more challenging in the context of thinking about law and religion is that we do not normally think of law as a system of meaning, or a set of symbols, that help to supply understanding about our worlds. My claim, however, is that law - and, for our purposes, Canadian constitutional rule of law in particularis precisely this.

I want to suggest that meaning-giving conceptions of things like space, time, authority, value, and the subject are embedded within the law. These conceptions afford meaning to the events that take place within and before the law. Canadian constitutional rule of law provides a very particular way of understanding and interpreting the meaning of experience and the significance of the events in our lives. Owing to this interpretive role and meaning-giving function, law is not an instrument brought to bear upon cultures; rather, it is itself a cultural system. ${ }^{5}$

Allow me to explain in more detail. My claim is more than just that law and religion can "believe in" or value different things, though this is certainly true. ${ }^{6}$ My claim is much more foundational and fundamental. Consider something as basic as conceptions of time and space. In comparative studies, there is wide

See generally Paul W. Kahn, The Cultural Study of Law: Reconstructing Legal Scholarship (Chicago and London: University of Chicago Press, 1999); and Naomi Mezey, "Law as Culture" in Austin Sarat \& Jonathan Simon eds., Cultural Analysis, Cultural Studies, and the Law: Moving Beyond Legal Realism (Durham, N.C. and London: Duke University Press, 2003) 37 .

${ }^{6}$ Indeed, the Canadian constitutional rule of law is deeply committed to the values and goods of liberalism. See Stephen Holmes, Passions and Constraint: On the Theory of Liberal Democracy (Chicago: University of Chicago Press, 1995); Allan C. Hutchinson \& Andrew Petter, "Private Rights/Public W rongs: The Liberal Lie of the Charter" (1988) 38:3 University of Toronto Law Journal 278; Benjamin L. Berger, "Using the Charter to Cure Health Care: Panacaea or Placebo?" (2003) 8:1 Review of Constitutional Studies 20. I accept Taylor's characterization of liberalism as, itself, "a fighting creed" Charles Taylor, "The Politics of Recognition" in Philosophical Arguments (Cambridge, Mass.: Harvard University Press, 1995) 225 at 249). In its appeal to constitutional and Charter values, the Supreme Court of Canada's jurisprudence confirms that the Canadian constitutional rule of law is committed to certain normative ends and visions of the good. See e.g. Reference re Secession of Quebec, [1998] 2 S.C.R. 217, online: CanLII $<$ http://www.canlii.org/ca/cas/scc/1998/1998scc63.html >; R. $v$. Big M Drug Mart Ltd., [1985] 1 S.C.R. 295, online: CanLII $<$ http://www.canlii.org/ca/cas/scc/1985/1985scc15.html >; Hill v. Church of Scientology of Toronto, [1995] 2 S.C.R. 1130 at 1169, online: CanLII <http://www.canlii.org/ca/cas/scc/1995/ $1995 \mathrm{scc} 67 . \mathrm{html}>$. acceptance of the thesis that religious cultures divide both time and space along the axis of the sacred and the profane. ${ }^{7}$ We view this kind of conception as immediately and obviously cultural. But what of law? Surely law contains no such created symbols to divide up time and space - no particular or readily identifiable conceptions of these dimensions of human experience.

In fact, the Canadian rule of law has very particular conceptions of both time and space. Space is relevant in the law to the extent and degree that one can exercise authority over that space. ${ }^{8}$ Thus, whereas space in religion is divided as between the sacred and the profane, the metaphor - the symbol - for law's organization of space is the notion of jurisdiction. So instead of understanding space in terms of the sacred and the profane, the law understands space in jurisdictional terms, terms that relate to international borders, the political and geographical borders within the nation-state, and even the border between private and public space. ${ }^{9}$

Time, too, has a particular meaning in the law. Just as time has particular dimensions of significance in religious cultures - the world is normally founded in some mythic past and bounded by an eschatological time, or a sense of purposeful eternity - so does law. By contrast, law's conception of time is far more accretative or accumulative. The idea of precedent, of the presence of all past decisions in the present and as guiding for the future, is its own conception of time. $^{10}$

See e.g., Mircea Eliade, The Sacred and the Profane; The Nature of Religion, trans. by Willard R. Trask (New York: Harcourt, Brace \& World, Inc., 1959).

8 For two works in the field of critical legal geography that explore the relationship between geography and the legal imagination, see Nicholas Blomley, Law, Space and the Geographies of Power (New York: Guilford Press, 1994) and Wesley Pue, "Wrestling with Law: (Geographical) Specificity v. (Legal) Abstraction" (1990) 11 Urban Geography 566.

$9 \quad$ See e.g., Russell Hogg, "Law's Other Spaces" (2002) 6 Law Text Culture 29 at 32 ("Law has a geography within, as well as beyond, the boundaries of nation states, even if one of its characteristic qualities has been to deny it").

10 See Martin Krygier, "Law as Tradition" (1986) 5 Law and Philosophy 237 at 245 ("the past of law . . is not simply part of its history; it is an authoritative part of the present"); and Paul W. Kahn, The Reign of Law: Marbury v. Madison and the Construction of America (New Haven and London: Yale University Press, 1997) at 21 ("In the present moment of law, we are always looking backward to determine how the future is to be ordered"). For the centrality of tradition to the rule of law, see also Anthony T. Kronman, "Precedent and Tradition" 
The same sort of point can be made about conceptions of authority. Whereas in religious culture, authority tends to come through institutional or textual sources grounded in some transcendental soil, a central component of law's notion of authority is the legitimate representation of the citizenry. To be sure, such representation requires reflection of current political will. ${ }^{11}$ What law's authority also depends upon, however, is that the law reflect the essential commitments and history of the country. ${ }^{12}$ Similarly, just as religions might have a particular concern for the subject perhaps in the "essential" or "eternal" aspect of the person - law too has a conception of subjectivity. Under the rule of law, the individual is relevantly divided into a public and private aspect ${ }^{13}$ and the law is primarily concerned with the human as a political actor - as citizen.

The point of all of this is to show that, like religion, law consists in a rich system of understandings and symbols that inform how the world is interpreted and what meanings are derived from experience. It is in this way that law and religion share a fundamental similarity - both are cultural systems.

(1990) 99:5 Yale Law Journal 1029

11 See Robert C. Post, "Democratic Constitutionalism and Cultural Heterogeneity" (2000) 25:2 Australian Journal of Legal Philosophy 185 at 186 ("Democratic states embody the value of collective self-governance, which requires that citizens come to accept their own 'authorship' of state actions and choices, or at least of the deliberative procedures through which the state reaches its decisions"). Korsgaard makes a similar argument in an article otherwise about the nature of individual agency: "A state is not merely a group of citizens living on a shared territory. We have a state only where these citizens have constituted themselves into a single agent. They have, that is, adopted a way of resolving conflicts, making decisions, interacting with other states, and planning together for an ongoing future." Christine M. Korsgaard, "Personal Identity and the Unity of Agency: A Kantian Response to Parfit" (1989) 18:2 Philosophy and Public Affairs 101 at 114.

12 For this notion of constitutional legal authority as stemming in part from the authority of "ethos," see Robert Post, Constitutional Domains: Democracy, Community, Management (Cambridge, Mass: Harvard University Press, 1995) at $35 \mathrm{ff}$. See also Hanna Fenichel Pitkin, "The Idea of a Constitution" (1987) 37:2 Journal of Legal Education 167 at 169 ("how we are able to constitute ourselves is profoundly tied to how we are already constituted by our own distinctive history. Thus there is a sense, after all, in which our constitution is sacred and demands our respectful acknowledgement. If we mistake who we are, our efforts at constitutive action will fail")

13 See e.g., Patricia Hughes, "The Intersection of Public and Private under the Charter" (2003) 52 University of New Brunswick Law Journal 201

\section{AN EXAMPLE}

Allow me now to offer a concrete example drawn from a forgotten corner of our public history. In this example you will see the way in which, rather than being a question of accommodation or "making space," the basic and incommensurable frameworks out of which meaning is constructed in law and religion, respectively, are the true source of the tension between the Canadian rule of law and religion.

In the fall of 1875, an election was approaching in the County of Charlevoix, Quebec. The Conservative party candidate was the Honourable Mr. Hector Louis Langevin and his Liberal opponent was Mr. Pierre-Alexis Tremblay. The Liberal party of the day took the position that there should be a sharp division between the Catholic Church and the state. Opposed to this notion and concerned with this election, the bishops of the ecclesiastical province responsible for the county circulated a pastoral letter on 22 September 1875, in which the following claim was made:

Men bent upon deceiving you, Our Dearly Beloved Brethren, incessantly repeat that religion has nothing to do with politics; that no attention should be paid to religious principles in the discussion of public affairs; that the clergy has duties to fulfill, but in the Church and the sacristy; and that in politics the people should practice moral independence!

Monstrous errors, O.D.B.B., and woe to the country wherein they should take root! By excluding the clergy, they exclude the Church, and by throwing the Church aside they deprive themselves of all the salutary and immutable principles she contains, God, morals, justice, truth; and when they have destroyed everything else, nothing is left them but force to rely upon! ${ }^{14}$

Provoked to action by this dispatch, the curés of Charlevoix appealed to the political and

Brassard et al. v. Langevin, [1877] 1 S.C.R. 145 at 153 [Brassard]. 
spiritual consciences of their congregations. They reminded their parishioners "that you shall have to render to God an account of the vote you will cast this week," 15 and warned them to "be careful never to taste the fruit of the tree Catholic Liberal."16

The Conservative candidate, Mr. Langevin, was elected in the early months of 1876 . However, his opponent, Mr. Tremblay, and a group of concerned citizens commenced a legal challenge to the validity of the election based upon the influence exerted by the clergy. On 28 February 1877, the Supreme Court of Canada unanimously annulled Mr. Langevin's election to the House of Commons. Justice Ritchie found that this case was not in any way about religion. Rather, the rule of law established a clear principle with which all could agree - the freedom of elections - and the court was bound to annul this election. In reaching this conclusion, Mr. Justice Ritchie declared that "the combined effects of the bishop's pastoral and the denunciations of the clergy so permeated the county as to make it impossible for me to say that there was a free election." "The law of the land is supreme," Justice Ritchie argued, "and we recognize no authority as superior or equal to it. Such ever has been and is, and I hope will ever continue to be, a principle of our Constitution." ${ }^{~ 18}$ The law - the Constitution - would not permit this election result to stand. In effect, the election was void owing to undue spiritual influence.

One view of this late nineteenth-century case is that it merely reflects an early phase in the development of the Canadian rule of law, in which the place of religion within the legal structure had not yet been settled. The country had only been established a decade earlier, and the constitutional compromise was marked by a much more complex legal status for religion than a clear separation of church and state. From this perspective, the tensions at play in Brassard v. Langevin would simply have to await a "right accommodation" of religion into the rule of law or a perfected understanding of pluralism and secularism.

In my view, this interpretation is only sustainable if, in favour of the most general

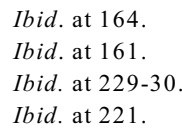

characterization of the issues, one glosses over the particular claims made by the competing positions - that of the religious, on the one hand, and the rule of law, on the other. The openness of language characteristic of this period gives us access to rhetoric that discloses a much deeper divide at play in this case. The claims at stake here go beyond questions of accommodation or secularism. With due attention to the commitments disclosed in both sets of arguments, the picture is one of a clash of foundational ways of giving meaning to experience, in this case the experience of a political election.

Consider the building-blocks that form each position. The pastoral letter and sermons admit of no ambiguity about their source of authority: legitimacy and authority flows in an unbroken chain from God, through the Pope and the Church, and is finally vested in the pastor. This authority is transcendental and, therefore, claimed to be supreme to any earthly institution. A clear concept of time is also at play in the sermons and letter: first, in that the Church's authority is timelessly old $^{19}$ and, second, in that the implications of this event ripple into the afterlife (and, indeed, into eternity). ${ }^{20}$ There is also a conception of the subject implicit in all of the religious rhetoric: the election is significant to the extent that it impacts upon the eternal soul of the voter, which is the aspect of the self at play in this drama. Furthermore, the pastoral letter and sermons assert the utter indivisibility of the religious and political self and, with it, the public and private aspects of subjectivity. Even notions of space are engendered by this debate, with the binding-ness of God's authority existing quite apart from any territorial conception; rather, the only "jurisdictions" engaged here are the profane - this world - and the sacred - the transcendent world invoked through myths and appeals to the afterlife.

The legal response discloses equally defined and influential positions on each of these topics. In

\footnotetext{
19 " $[\mathrm{T}]$ he forms of civil society vary with times and places; the Church was born on Calvary of the blood of a God, from His lips She has directly received her immutable constitution." Brassard, supra note at 153 , citing excerpts from the pastoral letter of the Bishop of the Ecclesiastic Province, 22 September, 1875 .

20 "[O]ne day God shall ask you to give an account of it before His formidable tribunal." Ibid. at 160, citing Analysis of a Sermon by Mr. Sirois, Priest and Curé of St. Paul's Bay.
} 
contrast to the transcendental authority and legitimacy structure of religion, authority from the perspective of the rule of law rests with the Sovereign and the Constitution. It was on this basis that Justice Ritchie was able to characterize the problem before the Court as a question of statutory civil rights "pure and simple." 21 The concept of time governing the response from the rule of law is, on one level, the electoral structure, but, more deeply, the "time" of law. Time is marked by legal events such as the Treaty of Paris and the Dominion Controverted Elections Act and, in this sense, lacks the eschatological prospectivity that characterizes the religious view. Under the rule of law, subjectivity is centred not on the notion of the soul, but on the concept of the citizen. $^{22}$ Of critical importance in treating the subject, then, is the unencumbered exercise of rights and worldly equality, ${ }^{23}$ not the ultimate fate of the divine breath within the person. As this decision shows, under the rule of law, space is carved up into jurisdictions, which bound power and affect the rights and obligations of the subject. $^{24}$

The basic concepts that inform the two perspectives at stake in this case are manifestly at odds with one another. Given its conceptual commitments, the Church could only view this election and the clergy's involvement in it as a question of spiritual conscience and divine will. From the perspective of the rule of law, the question is wholly one of rights and duties in the context of a legal event, and could not be otherwise. The sources of authority are incommensurable and the very conceptions of what is essential about the human subjects involved diverge; indeed, time and space have vastly different contours in each. Furthermore, subtending all of these differences are foundational normative commitments. There is no point of meeting, no space for negotiation, on this

Ibid. at 215 .

"Clergymen, I say, are citizens, and have all the freedom and liberty that can possibly belong to laymen, but no other or greater." Ibid. at 222

23 "There is no man in this Dominion so great as to be above the law, and none so humble as to be beneath its notice." Ibid. at 220 .

24 "So long as a man, whether clerical or lay, lives under the Queen's protection in the Queen's dominion, he must obey the laws of the land, and if he infringes them he is amenable to the legal tribunals of the country - the Queen's Courts of Justice." Ibid. at 220 . terrain. For one view to yield to the other would involve the sacrifice of a constituent element of their meaning-giving frameworks. Brassard shows a conflict of worldviews, a clash of cultures.

\section{CONCLUSION: THE ChALLENGES}

I began this piece by describing a failing in our conventional idiom used to describe the relationship between law and religion. Instead, I have suggested that we must reconceive of the Canadian constitutional rule of law as itself a culture and, therefore, must re-imagine the relationship between law and religion as the interaction of two cultural systems. However, viewing the problem in this way poses certain significant challenges.

First, "understanding" becomes critically important. Like any clash or meeting of cultures, there is no way of living together until there is some mutual understanding. This is the aim of my account of the interaction between law and religion: understanding the claims of law and those of religion in a more complex and nuanced way through a language of contrast and commonality. ${ }^{25}$ Once these claims are cast in terms that give due regard to the fullness of the worldviews out of which both religion and the constitutional rule of law are operating, the challenge is to find points - and I believe there to be many - across which constructive conversations can take place. Understanding the interaction of law and religion in a manner that avoids reductionism offers an opportunity to identify both aspects of the meaning-giving frameworks that may be drawn together and harmonized in public life.

Second, however, we must recognize that, given the fundamental level at which this tension develops - at the level of meaning - there are points of incommensurability, points of irresolvable difference between law and religion. Exposing the full richness of the cultures of

See Benjamin L. Berger, "The Limits of Belief: Freedom of Religion, Secularism, and the Liberal State" (2002) 17:1 Canadian Journal of Law and Society 39, discussing the use in liberal secular society, properly understood, of Charles Taylor's notion of a "language of perspicuous contrast." See also Charles Taylor, "Understanding and Ethnocentricity" in Philosophy and the Human Sciences: Philosophical Papers 2 (Cambridge: Cambridge University Press, 1985) 116 at 125-26. 
religion and the Canadian constitutional rule of law will not only reveal points of potential harmonization and convergence. It is inevitable that such an account will also expose elements of each that are uncompromisingly inconsistent with those of the other. Then the challenge is to reason in a principled manner about what to do in such situations. When the culture of the rule of law and a religious culture lock in such a moment of incommensurability, the exigencies of having a functioning public life demand that something be done. In such situations we have to decide among interpretations of the world; one meaning or the other must prevail.

We cannot discuss it at any length here, but it is my view that, subject to developing a process for better mutual understanding, it is the public sphere, the culture of Canadian constitutionalism, that must prevail at these points of profound tension. I fully acknowledge that once we have discussed the similar natures of law and religion, once we have confirmed a kind of equivalency as between the two, this assertion might be hard to accept. If both religion and the constitutional rule of law are simply ways of giving meaning to the world based on a set of symbols and categories of thought, what warrants the privileging of one culture over another? My sense is that the answer lies in the exigency - the urgency - of having some means of living together and, relatedly, in the concept of the secular. ${ }^{26}$ In a pluralistic society, some sense of the common good must prevail over provincialism. Effectively, the answer must always relate to the importance of public life and of having a civic culture.

Our immediate task, however, is to develop a helpful and satisfying account of what is at play in the interaction of law and religion. That is the goal of this piece. It is only with such an account in hand that we can begin to make sense of this pressing issue of public policy.

\section{Benjamin L. Berger}

Assistant Professor

Faculty of Law, University of Victoria

bberger@uvic.ca

26 See Berger, ibid., providing a definition of the secular and critiquing the conception offered in Benson, supra note 2. 